\title{
PENATALAKSANAAN FISIOTERAPI PADA KETERBATASAN LINGKUP GERAK SENDI BAHU AKIBAT POST ORIF \\ FRAKTUR SHAFT HUMERUS DEXTRA \\ DI KELURAHAN ALALAK UTARA \\ BANJARMASIN TAHUN 2018 \\ (Management of Physiotherapy on Range of Motion Limitation due to Post Orif Fracture of Shaft Humerus Dextra In Kelurahan \\ Alalak Utara Banjarmasin on 2018)
}

\author{
Mar'atus Sa'diah, A.Md.Kes \\ Program Studi D-III Fisioterapi \\ Politeknik Unggulan Kalimantan \\ Email: politeknikunggulankalimantan@yahoo.co.id
}

\begin{abstract}
Fractures of the humerus is an interruption of the continuity condition of the upper arm bone tissue caused by collision or trauma directly or indirectly. Fractures can cause pain, swelling, spasms, decreased muscle strength and muscle wasting. Fractures of the humerus also resulted in limited range of motion (ROM) joint in the shoulder and elbow. The purpose of this study to determine whether there is an increase in the ROM on the right shoulder that has limited the use of exercise therapy intervention in the form of passive and active exercise and hold relax. Research using case study method in one type of cases with a single sample, is given a dose of 6 times the treatment within 3 weeks. The result is an increase in ROM right shoulder evaluated using a goniometer, the comparison between T1 to T6 is S. $40^{\circ}-0^{\circ}-120^{\circ}$ became S. $50^{\circ}-0^{\circ}-140^{\circ}, \mathrm{F}$. $100^{\circ}-0^{\circ}-60^{\circ}$ into F. $110^{\circ}-0^{\circ}-70^{\circ}$ and R do not become R. $75^{\circ}-0^{\circ}-80^{\circ}$.
\end{abstract}

\section{Keywords: fractures, humerus, ROM, exercise therapy}

\begin{abstract}
ABSTRAK
Fraktur humerus merupakan suatu kondisi terputusnya kontinuitas jaringan tulang lengan atas yang disebabkan oleh benturan atau trauma langsung maupun tidak langsung. Terjadinya fraktur dapat menyebabkan timbulnya nyeri, bengkak, spasme, penurunan kekuatan otot dan pengecilan otot. Fraktur humerus juga mengakibatkan keterbatasan Lingkup Gerak Sendi (LGS) pada bahu dan siku. Tujuan penelitian ini untuk mengetahui ada tidaknya peningkatan LGS pada bahu kanan yang mengalami keterbatasan dengan menggunakan intervensi exercise therapy berupa passive dan active exercise serta hold relax. Penelitian menggunakan metode case study pada 1 jenis kasus dengan sampel tunggal, diberikan dosis 6 kali perlakuan dalam waktu 3 minggu. Hasilnya terjadi peningkatan LGS bahu kanan yang dievaluasi menggunakan goniometer, perbandingan antara $T_{1}$ dengan $T_{6}$ yaitu $S .40^{\circ}-0^{\circ}-120^{\circ}$ menjadi $S .50^{\circ}-0^{\circ}-140^{\circ}$, F. $100^{\circ}-0^{\circ}-$ $60^{\circ}$ menjadi F. $110^{\circ}-0^{\circ}-70^{\circ}$ dan R belum dapat dilakukan menjadi R. $75^{\circ}-0^{\circ}-80^{\circ}$.
\end{abstract}

Kata Kunci: fraktur, humerus, LGS, exercise therapy 


\section{PENDAHULUAN}

Cedera yang sering terjadi pada tulang umumnya dikenal dengan patah tulang atau fraktur. Fraktur merupakan suatu kondisi diskontinuitas tulang atau terputusnya kontinuitas jaringan tulang yang umumnya disebabkan oleh rudapaksa atau trauma, baik trauma langsung maupun trauma tidak langsung (Hoppenfield, 2011). Fraktur dapat terjadi pada seluruh tulang, salah satunya adalah fraktur humerus. Fraktur humerus adalah fraktur pada tulang terpanjang dan terbesar dari ekstremitas superior yang disebabkan oleh benturan atau trauma langsung maupun tidak langsung (de Jong, 2010; Kurnia, 2015).

Fraktur dapat mengakibatkan terjadinya keterbatasan gerak, terutama di daerah sendi yang fraktur dan sendi yang ada di daerah sekitarnya. Karena keterbatasan gerak tersebut mengakibatkan terjadinya keterbatasan lingkup gerak sendi dan gangguan pada fleksibilitas sendi (Gusty \& Armayanti, 2014). Lingkup Gerak Sendi (LGS) adalah istilah yang digunakan untuk menjelaskan jauhnya jangkauan dari gerak sendi (Pangemanan et al., 2012).

Menurut World Health Organization (WHO) prevalensi fraktur secara umum yang terjadi di dunia kurang lebih 13 juta orang pada tahun 2008 dengan angka prevalensi sebesar 2,7\%. Sementara pada tahun 2009 terdapat kurang lebih 18 juta orang mengalami fraktur dengan angka prevalensi $4,2 \%$. Adapun pada tahun 2010 meningkat menjadi 21 juta orang dengan angka prevalensi 3,5\% (Sari, 2016).

Fraktur humerus yang menyebabkan keterbatasan LGS bahu membuat penderita mengalami kesulitan dalam menggerakkan tangan, seperti gerakan mengangkat tangan keatas, mengayunkan tangan kedepan dan kebelakang, serta membuka tangan ke arah samping. Aktivitas sehari-hari penderita juga ikut terganggu dikarenakan tidak leluasanya tangan untuk bergerak, seperti mandi, mengangkat barang berat, mengambil atau mengembalikan benda ditempat tinggi dan berkendara. Sehingga diperlukan penanganan medis salah satunya penanganan terapi oleh Fisioterapis. Fisioterapis dengan berbagai modalitas terapi latihan dapat menurunkan nyeri dan meningkatkan LGS sehingga penderita dapat beraktivitas dan produktif kembali. Intervensi fisioterapi yang dapat diberikan adalah terapi latihan menggunakan metode passive exercise, active exercise dan hold relax. Passive exercise adalah suatu latihan yang dilakukan dengan gerakan yang dihasilkan dengan tenaga atau kekuatan dari luar tanpa adanya kontraksi otot. Sedangkan active exercise merupakan gerak yang dihasilkan oleh kontraksi otot itu sendiri (Romadloni, 2013). Adapun hold relax merupakan metode untuk memajukan atau mempercepat respon dari mekanisme neuromuscular melalui rangsangan pada propioseptor (Kisner \& Colby, 2013).

Berdasarkan latar belakang di atas dan tingginya angka kejadian fraktur humerus di Banjarmasin yaitu 48 pasien pertahun yang apabila tidak diberikan intervensi maka mereka terkendala dalam beraktivitas sehari-hari, sehingga penulis tertarik untuk mengangkat tema mengenai "Penatalaksanaan Fisioterapi pada Keterbatasan Lingkup Gerak Sendi Bahu akibat Post ORIF Fraktur Shaft Humerus di Kelurahan Alalak Utara Banjarmasin Tahun 2018”.

\section{METODE PENELITIAN}

Penelitian ini dilakukan di Kelurahan Alalak Utara, Kecamatan Banjarmasin Utara, Kota Banjarmasin. Adapun waktu penelitian dilakukan dalam jangka waktu 3 minggu dari 13 Mei - 10 Juni 2018 dengan frekuensi 2 kali pertemuan dalam 1 minggu. Jenis penelitian yang dilakukan adalah metode case study atau studi kasus. Studi kasus ialah serangkaian kegiatan ilmiah yang dilakukan secara intensif, terinci dan mendalam tentang program, peristiwa, dan aktifitas, baik pada perorangan, sekelompok orang, lembaga atau organisasi untuk memperoleh pengetahuan mendalam tentang peristiwa tersebut (Rahardjo, 2017).

Instrumen penelitian yang digunakan oleh peneliti yaitu goniometer. Goniometer adalah alat ukur lingkup gerak sendi (LGS) yang merupakan alat sangat penting bagi fisioterapis. Goniometer berfungsi sebagai alat pemeriksaan dan alat evaluasi yang dapat digunakan untuk menentukan posisi sendi yang tepat dan jumlah total dari gerakan yang dapat terjadi pada suatu sendi (Irfan et al., 2013). 
Penulisan LGS dalam metode Internasional Standard Orthopedic Measurement (ISOM) dengan 3 kelompok angka, mulai dari semua gerakan yang menjauhi tubuh ditulis pertama, kemudian posisi awal ditulis di tengah, lalu semua gerakan yang mendekati tubuh di tulis terakhir. Semua gerakan diukur dari posisi awal atau anatomis, sebelum penulisan 3 angka terlebih dahulu menulis bidang gerak. Sagital utntuk bidang gerak ekstensi-fleksi disingkat $\mathrm{S}$, frontal untuk bidang gerak abduksi-adduksi disingkat $\mathrm{F}$, dan rotasi untuk bidang gerak eksorotasi-endorotasi disingkat R (Mirza, 2012). Pelaksanaan pengukuran goniometer dilakukan pre dan post intervensi fisioterapi.

\section{HASIL PENELITIAN} minggu:

Berikut ini merupakan grafik dari evaluasi LGS bahu kanan selama 6 kali pertemuan dalam 3

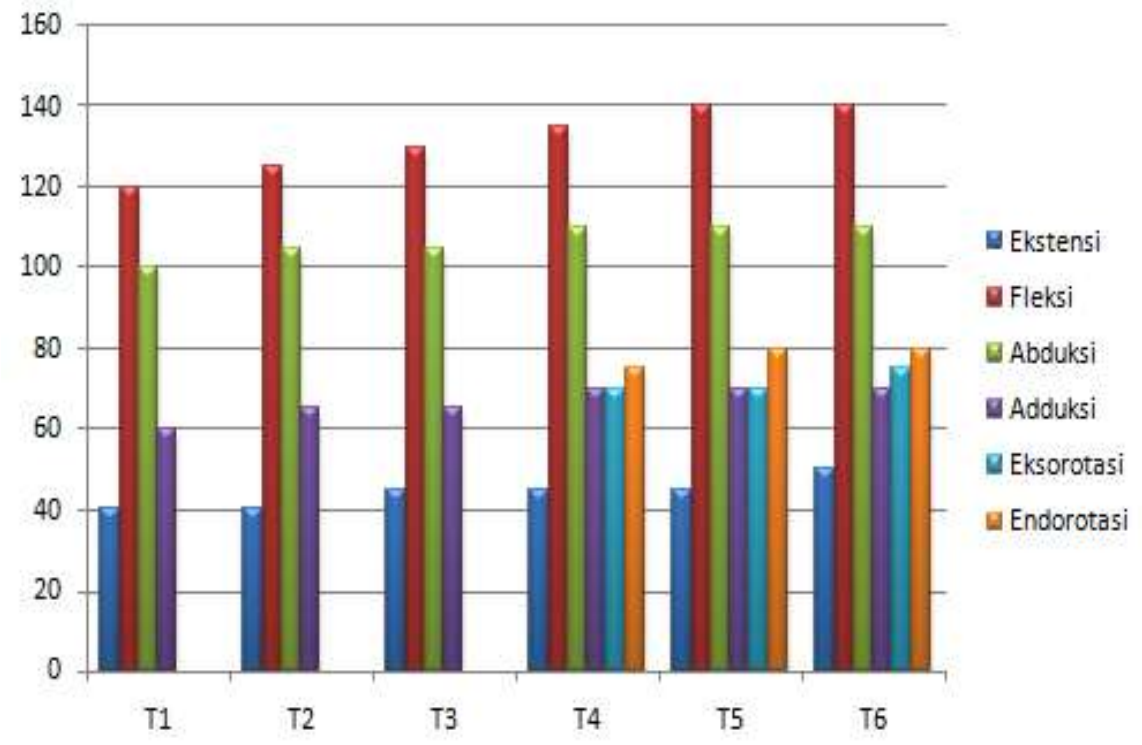

Berdasarkan grafik tersebut, LGS bahu kanan secara aktif pada minggu pertama pertemuan I $\left(\mathrm{T}_{1}\right)$ didapat hasil pengukuran yang sama antara pre dan post intervensi pada semua gerakan sendi bahu kanan, yaitu S. $40^{\circ}-0^{\circ}-120^{\circ}$ dan F. $100^{\circ}-0^{\circ}-60^{\circ}$, kecuali gerakan ekso-endorotasi yang belum diukur dengan goniometer dikarenakan pasien belum dapat menekuk siku sehingga titik letak untuk goniometer pada olecranon tidak didapati. Belum terjadinya peningkatan LGS pada minggu pertama dikarenakan pasien yang baru pertama kali diberikan intervensi berupa exercise therapy yakni passive exercise, active exercise dan hold relax. Pada $\mathrm{T}_{1}$ ini intensitas exercise therapy berupa passive exercise dan active exercise yang diberikan belum sesuai dengan dosis yang diperlukan untuk peningkatan LGS, yaitu hanya 5 kali pengulangan masing-masing pada semua gerakan. Sedangkan hold relax diberikan sesuai dosis yaitu 4 kali pengulangan pada semua LGS bahu yang mengalami keterbatasan.

Pada pertemuan II $\left(\mathrm{T}_{2}\right)$ pengukuran dengan goniometer antara pre dan post intervensi, yaitu pre S. $40^{\circ}-0^{\circ}-120^{\circ}$ dan F. $100^{\circ}-0^{\circ}-60^{\circ}$ menjadi post S. $40^{\circ}-0^{\circ}-125^{\circ}$ dan F. $105^{\circ}-0^{\circ}-65^{\circ}$. Untuk fleksi dan abduksi-adduksi meningkat $5^{\circ}$, ekstensi tetap, sedangkan untuk ekso-endorotasi masih belum didapat pengukuran. Perbandingan antara $T_{1}$ dengan $T_{2}$ masih sedikit terjadinya peningkatan LGS bahu kanan, yaitu hanya meningkat $5^{\circ}$ pada fleksi dan abduksi-adduksi. Pemberian intervensi pada $T_{2}$ intensitas passive-active exercise meningkat dari 5 kali menjadi 8 kali pengulangan.

Pada minggu kedua pertemuan III $\left(\mathrm{T}_{3}\right)$ didapat hasil pengukuran adanya peningkatan, yaitu pre S. $40^{\circ}-0^{\circ}-125^{\circ}, \mathrm{F} .105^{\circ}-0^{\circ}-65^{\circ}$ menjadi post S. $45^{\circ}-0^{\circ}-130^{\circ}$, F. $105^{\circ}-0^{\circ}-60^{\circ}$ dan untuk ekso-endorotasi juga belum didapat. Peningkatan yang terjadi pada $\mathrm{T}_{3}$ yaitu ekstensi-fleksi dan adduksi meningkat $5^{\circ}$. Perbandingan antara $T_{1}$ dengan $T_{3}$ terjadi peningkatan $10^{\circ}$ pada fleksi, $5^{\circ}$ pada ekstensi dan abduksi-adduksi, pada ekso-endorotasi yang belum didapat. Pemberian 
passive-active exercise pada $T_{3}$ meningkat dari 8 kali menjadi 10 kali pengulangan sesuai dengan dosis yang telah ditentukan.

Selanjutnya pada pertemuan IV $\left(\mathrm{T}_{4}\right)$ didapat hasil adanya peningkatan antara pre dan post intervensi, yaitu pre S. $45^{\circ}-0^{\circ}-130^{\circ}$ dan F. $105^{\circ}-0^{\circ}-65^{\circ}$ menjadi post S. $45^{\circ}-0^{\circ}-130^{\circ}$ dan F. $105^{\circ}-0^{\circ}-70^{\circ}$. Pada gerakan ekso-endorotasi sudah dapat dilakukan pengukuran LGS dan didapat nilai tetap antara pre dan post yaitu R. $70^{\circ}-0^{\circ}-75^{\circ}$. Peningkatan yang terjadi pada $\mathrm{T}_{4}$ adalah hanya adduksi yaitu $5^{\circ}$, sedangkan perbandingan antara $T_{1}$ dengan $T_{4}$ terjadi peningkatan $5^{\circ}$ pada ekstensi, $15^{\circ}$ pada fleksi, $10^{\circ}$ pada abduksi-adduksi dan ekso-endorotasi belum ada terjadi peningkatan.

Pada minggu ketiga pertemuan $\mathrm{V}\left(\mathrm{T}_{5}\right)$ didapat hasil pengukuran pada semua LGS bahu kanan pasien, yaitu pre S. $45^{\circ}-0^{\circ}-130^{\circ}, \mathrm{F} .105^{\circ}-0^{\circ}-70^{\circ}$ dan R. $70^{\circ}-0^{\circ}-75^{\circ}$ menjadi post $\mathrm{S}$. $50^{\circ}-0^{\circ}-135^{\circ}, \mathrm{F} .110^{\circ}-0^{\circ}-70^{\circ}$ dan R. $70^{\circ}-0^{\circ}-80^{\circ}$. Peningkatan yang terjadi antara pre dan post di $\mathrm{T}_{5}$ adalah meningkat $5^{\circ}$ pada ekstensi-fleksi, abduksi dan endorotasi. Sedangkan perbandingan antara $T_{1}$ dengan $T_{5}$ adalah terjadi peningkatan $5^{\circ}$ pada ekstensi, $20^{\circ}$ pada fleksi, $10^{\circ}$ pada abduksi-adduksi dan pada ekso-endorotasi dari belum didapat meningkat $5^{\circ}$ pada endorotasi.

Pada pertemuan terakhir $\left(\mathrm{T}_{6}\right)$ hasil pengukuran yang didapat menggunakan goniometer yaitu pre S. $50^{\circ}-0^{\circ}-135^{\circ}, \mathrm{F} .110^{\circ}-0^{\circ}-70^{\circ}$ dan R. $70^{\circ}-0^{\circ}-80^{\circ}$ menjadi post S. $50^{\circ}-0^{\circ}-140^{\circ}$, F. $110^{\circ}$ - $0^{\circ}-70^{\circ}$ dan R. $75^{\circ}-0^{\circ}-80^{\circ}$. Pada pertemuan ini $\left(T_{6}\right)$ terjadi peningkatan $5^{\circ}$ pada fleksi dan eksorotasi, gerakan lainnya antara pre dan post tetap atau tidak terjadi peningkatan LGS. Sedangkan perbandingan antara $T_{1}$ dengan $T_{6}$ adalah terjadi peningkatan $20^{\circ}$ pada fleksi, $10^{\circ}$ pada ekstensi dan abduksi-adduksi, serta $5^{\circ}$ pada ekso-endorotasi, yang mana ekstensi dan adduksi mencapai nilai LGS penuh.

Berdasarkan penjelasan diatas meningkatnya LGS bahu kanan pasien dengan intervensi exercise therapy metode active exercise, passive exercise dan hold relax selama 6 kali pertemuan dalam 3 minggu ( $2 x /$ minggu) meningkatkan $20^{\circ}$ pada fleksi, $10^{\circ}$ pada ekstensi dan abduksi-adduksi, dan $5^{\circ}$ pada ekso-endorotasi. Dengan hasil yang didapatkan sekarang dapat dilihat bahwa LGS masih ada yang terbatas, sehingga diperlukan penambahan waktu terapi untuk memberikan intervensi agar semua LGS yang masih terbatas dapat mencapai nilai normalnya.

\section{PEMBAHASAN}

Exercise therapy atau terapi latihan merupakan salah satu usaha dalam pengobatan fisioterapi yang didalam pelaksanaannya menggunakan latihan-latihan gerak baik secara aktif maupun pasif dengan sasaran orang yang sehat maupun sakit (Luklukaningsih, 2014). Exercise therapy bertujuan untuk mencegah proses perlengketan jaringan agar memelihara kebebasan gerak sendi, meningkatkan lingkup gerak sendi, memelihara ekstensibilitas otot dan mencegah pemendekan otot, serta memperlancar sirkulasi darah dan rileksasi (Wahyono \& Budi, 2016).

Pemberian intervensi exercise therapy yang dilakukan kepada pasien diawali dengan passive exercise kemudian active exercise, hal ini sesuai dengan penelitian yang dilakukan oleh Syukur (2014) bahwa pemberian passive exercise dan active exercise secara dini bertujuan mencegah perlengketan jaringan, menjaga elastisitas dan kontraktilitas jaringan otot serta mencegah pembentukan inflamasi dalam rongga persendian sehingga LGS terpelihara. Pemberian passive exercise dan active exercise dilakukan oleh Syukur (2014) dalam 6 kali pertemuan dengan hasil LGS meningkat $5^{\circ}$.

Passive exercise adalah latihan gerakan yang dihasilkan dengan tenaga atau kekuatan dari luar tanpa adanya kontraksi otot (Romadloni, 2013). Bertambahnya LGS menggunakan intervensi exercise therapy metode passive exercise sesuai dengan mekanisme terstimulusnya muscle spindle organs (MSO) pada saat otot rileks. MSO sangat sensitif terhadap perubahan panjang (length) otot, yang mana ketika otot dalam keadaan rileksasi responnya berupa mempertahankan panjang (tonic response) untuk memelihara posisi atau mengubah panjang (phasic response) saat bergerak. Pergerakan secara pasif tidak menimbulkan kontraksi pada otot agonis dan otot antagonis, sehingga MSO terstimulus pada kedua otot yang rileks dan pada akhirnya pergerakan baik ke arah agonis maupun antagonis menjadi lebih mudah dan lebih leluasa, maka dengan demikian LGS dapat menjadi bertambah (Wahyono \& Budi, 2016). 
Active exercise atau latihan gerak aktif yang dihasilkan oleh kontraksi otot itu sendiri (Romadloni, 2013) jika diberikan selama 6 kali terapi diketahui dapat meningkatkan kekuatan otot. Hal ini karena pada suatu gerakan tubuh selalu diikuti oleh kontraksi otot, kontraksi otot tergantung dari banyaknya motor unit yang terpasang. Dengan demikian kekuatan otot dan daya tahan otot pun menjadi meningkat dengan dilakukannya gerakan secara aktif (Syukur, 2014). Penelitian lainnya oleh Kurniasari (2010) dan Nugroho (2010) setelah pemberian intervensi active exercise sebanyak 6 kali pertemuan hasilnya LGS meningkat $10^{\circ}$. Pergerakan aktif dalam menambah LGS karena adanya rangsangan propiseptif dengan perubahan panjang otot pada saat terjadi kontraksi otot, darah bergerak ke jaringan sehingga pada sendi terjadi penambahan nutrisi, lalu perlengketan jaringan dapat dicegah, maka dengan demikian LGS dapat menjadi bertambah (Wahyono \& Budi, 2016).

Pemberian intervensi yang terakhir untuk meningkatkan LGS bahu kanan pasien dengan hold relax, hold relax bermanfaat untuk rileksasi otot-otot dan menambah LGS serta dapat untuk mengurangi nyeri (Nugroho, 2010). Menurut berbagai penelitian terdahulu menyimpulkan bahwa latihan dengan metode hold relax berpengaruh lebih baik untuk meningkatkan LGS dibandingkan dengan penguluran pasif (Wahyono \& Budi, 2016). Hal ini terbukti dengan penelitian yang telah dilakukan Bharata (2013) untuk menambah LGS menggunakan hold relax mengalami peningkatan $20^{\circ}$ setelah 6 kali diterapi. Sama halnya dengan penelitian oleh Pambudi (2014) dalam meningkatkan LGS bahu kiri mengalami peningkatan $15^{\circ}$ pada fleksi bahu, $5^{\circ}$ pada abduksiadduksi bahu dan $5^{\circ}$ pada eksorotasi bahu setelah 6 kali diterapi.

Pengaruh hold relax yang lebih baik untuk peningkatan LGS bahu kanan tersebut sesuai dengan mekanisme yang terjadi pada muscle spindle organs (MSO) dan golgi tendo organs (GTO). GTO merupakan reseptor yang ada diantara tendon otot dan serabut otot yang berfungsi membangkitkan inhibitory (hambatan) kekuatan impuls motorik yang menuju otot, sehingga mengurangi kekuatan kontraksi otot. GTO distimulasi oleh adanya ketegangan yang dihasilkan oleh serabut otot. Ketika GTO terstimulus maka GTO akan melepaskan impuls yang diteruskan ke medulla spinalis, dan di medulla spinalis impuls GTO akan membangkitkan mekanisme inhibitory sehingga akan menghambat kekuatan impuls motorik yang menuju otot (Wahyono \& Budi, 2016).

Hold relax merupakan teknik penguluran yang diawali dengan kontraksi isometrik otot antagonis. Kontraksi isometrik berarti tidak menstimulus MSO pada otot antagonis, sehingga tidak terjadi perubahan panjang otot. Sebaliknya pada otot agonis MSO terstimulus, sehingga terjadi perubahan panjang otot dan pada akhirnya pergerakan ke arah agonis menjadi lebih mudah dan lebih luas. Teknik hold relax yang diawali dengan kontraksi isometrik otot antagonis berarti terjadi adanya kontraksi otot antagonis. Hal ini berdampak terstimulusnya GTO yang membangkitkan mekanisme inhibitory, akibatnya menghambat kekuatan impuls motorik yang menuju otot antagonis. Terhambatnya impuls motorik pada otot antagonis tersebut berdampak terhadap melemahnya kontraksi otot antagonis, sehingga hambatan kinerja otot antagonis menurun diikuti kinerja otot agonis yang juga menjadi turun, akibatnya gerakan ke agonis menjadi lebih mudah dan lebih luas. Di samping itu, penurunan kontraksi antagonis berarti penurunan ketegangan otot, sehingga stimulus pada nociceptor (organ penerima rangsang nyeri) juga ikut menurun, akibatnya tidak membangkitkan nyeri (Wahyono \& Budi, 2016) dan nyeri dapat menjadi berkurang.

\section{KESIMPULAN}

Setelah dilakukan pemeriksaan, pengukuran dan tindakan terapi selama 6 kali pertemuan dalam waktu 3 minggu (2x/minggu) pada pasien bernama Ny. I berusia 50 tahun, penjelasannya disimpulkan sebagai berikut:

1. Diagnosa fisioterapi adalah gangguan aktifitas fungsional tangan kanan (menulis, memasak, mengangkat beban, berkendara dan toileting) akibat post ORIF fraktur shaft humerus dextra sejak 7 bulan yang lalu.

2. Problematik fisioterapi yang diteliti berfokus pada problematik keterbatasan LGS bahu kanan.

3. Tujuan fisioterapi pada problematik keterbatasan LGS bahu kanan adalah untuk meningkatkan LGS bahu kanan. 
4. Intervensi fisioterapi yang diberikan yaitu exercise therapy metode passive exrcise, active exercise dan hold relax. Dosis pemberian intervensi yaitu frekuensinya $2 x /$ minggu selama 3 minggu, waktunya 10 menit/intervensi, dan intensitas passive - active exercise 10 kali pengulangan, sedangkan untuk intensitas hold relax 4 kali pengulangan.

5. Evaluasi yang dilakukan pre dan post intervensi dibandingkan antara $T_{1}$ dengan $T_{6}$ didapatkan hasil pada S. $40^{\circ}-0^{\circ}-120^{\circ}$ menjadi S. $50^{\circ}-0^{\circ}-140^{\circ}$, F. $100^{\circ}-0^{\circ}-60^{\circ}$ menjadi F. $110^{\circ}-0^{\circ}-$ $70^{\circ}$ dan $R$ yang awalnya belum dapat dilakukan, baru pada $T_{4}$ didapat hasil pengukuran $R .70^{\circ}$ - $0^{\circ}-75^{\circ}$ dan pada $T_{6}$ menjadi R. $75^{\circ}-0^{\circ}-80^{\circ}$. Artinya terdapat peningkatan pada masingmasing gerakan, yaitu $20^{\circ}$ pada fleksi, $10^{\circ}$ pada ekstensi dan abduksi-adduksi, juga $5^{\circ}$ pada ekso-endorotasi.

\section{SARAN}

1. Kepada Peneliti, Menambah jangka waktu pemberian intervensi fisioterapi agar pada bahu kanan yang masih mengalami keterbatasan LGS dapat mencapai nilai normalnya.

2. Kepada Pasien, Tetap menerapkan edukasi yang telah diberikan dan melakukan latihan yang telah diprogramkan agar LGS yang masih mengalami keterbatasan dapat mencapai nilai normalnya. Lebih baiknya pasien juga tetap melakukan terapi baik di rumah sakit maupun klinik fisioterapi terdekat, karena setelah LGS penuh tercapai, tujuan selanjutnya adalah peningkatan kekuatan otot.

3. Kepada Fisioterapis, Dalam menangani kasus-kasus fisioterapi sangat perlu mengidentifikasi problematik yang muncul dan mampu memberikan intervensi fisioterapi yang tepat.

4. Kepada Institusi Pendidikan, Disarankan untuk tetap membimbing dan memperhatikan mahasiswa yang sedang melakukan proses penelitian hingga akhir, serta menyediakan fasilitas yang lebih agar dapat mendukung terciptanya hasil penelitian yang baik dan sempurna.

5. Kepada Masyarakat, Disarankan bila bertemu pasien dengan kondisi fraktur segera mencari pengobatan ke dokter atau tim medis lain untuk memperoleh pertolongan yang tepat, karena semakin cepat mendapatkan pengobatan atau fisioterapi, maka akan semakin baik hasilnya dan cepat dalam penyembuhannya. Diharapakan pula agar selalu peduli menjaga kesehatan, karena mencegah lebih baik daripada mengobati.

\section{PENGHARGAAN}

1. Kepada Ibu Enny Fauziah, S.Fis., M.Erg selaku dosen dan pembimbing KTI I.

2. Kepada Bapak H. Rusdiansyah, SH., MH., MMKes selaku dosen dan pembimbing KTI II.

\section{DAFTAR PUSTAKA}

Bharata, E. W. (2013). Penatalaksanaan fisioterapi dengan terapi latihan pada kasus fraktur subtrochantor femur sinistra di RS PKU Muhammadiyah Yogyakarta. KTI. Surakarta: Universitas Muhammadiyah Surakarta.

de Jong, W. (2010). Buku ajar ilmu bedah edisi 3. Jakarta: EGC.

Gusty, R. P., \& Armayanti. (2014). Pemberian latihan rentang gerak terhadap fleksibilitas sendi anggota gerak bawah pasien fraktur femur terpasang fiksasi interna di RSUP. Dr. M. Djamil Padang. Jurnal Keperawatan, 10(1), 176 - 196.

Hoppenfeid, S., \& Myrthy, V. L. (2011). Treatment \& rehabilitation of fractures. Jakarta: EGC.

Irfan, M., Wismanto, \& Abdul, C. M. (2013). Modul praktikum mata kuliah pengukuran fisioterapi. Jakarta: UEU Library.

Kisner, C., \& Colby, L. (2013). Theraupetic exercise foundation and techniques. (6th ed. Volume 1). Philadelphia: F.A. Davis Company. 
Kurnia, N. (2015). Perbedaan nilai range of motion (rom) sendi ekstremitas atas sebelum dan sesudah pelatihan senam lansia menpora pada kelompok lansia kemuning banyumanik semarang. KTI. Semarang: Universitas Diponegoro.

Kurniasari, S. N. (2010). Penatalaksanaan terapi latihan pada kondisi paska operasi pertrokanter femur dekstra dengan pemasangan plate and screw. Jurnal Pena, 19(1), 48-57.

Luklukaningsih, Z. (2014). Anatomi, fisiologi dan fisioterapi. Yogyakarta: Nuha Medika.

Mirza, Y. (2012). Pemberian latihan contract relax dan mobilisasi sendi untuk peningkatan lingkup gerak sendi flexi shoulder pada lansia. Skripsi. Surakarta: Universitas Muhammadiyah Surakarta.

Nugroho, H. W. (2013). Penatalaksanaan fisioterapi pada post operasi fracture collum femur dextra dengan pamasangan austin moore prothese (amp) di rsud pandanarang boyolali. KTI. Surakarta: Universitas Muhammadiyah Surakarta.

Pambudi, B. (2014). Penatalaksanaan fisioterapi pada fraktur humeri 1/3 proksimal sinistra di rsud sragen. KTI. Surakarta: Universitas Muhammadiyah Surakarta.

Pangemanan, D. H. C., Engka, J. N. A., \& Supit, S. (2012). Gambaran kekuatan otot dan fleksibilitas sendi ekstremitas atas dan ekstremitas bawah pada siswa/i smkn 3 manado. Jurnal Biomedik, 4(3), 109-118.

Rahardjo, M. (2017). Studi kasus dalam penelitian kualitatif konsep dan prosedurnya. Tesis. Malang: Universitas Islam Negeri Maulana Malik Ibrahim.

Romadloni, A. Y. (2013). Penatalaksanaan terapi latihan pada post operasi fraktur femur dextra $1 / 3$ tengah dengan pemasangan plate and screws di RS Orthopedi Prof Dr. Soeharso Surakarta. KTI. Surakarta: Universitas Muhammadiyah Surakarta.

Sari, Ni Kadek D. D. (2016). Prevalensi fraktur humerus di RSUP Sanglah pada bulan april 2015 desember 2016. KTI. Bali: Universitas Udayana.

Syukur, A. (2014). Penatalaksanaan fisioterapi pada kasus post orif fraktur tibia 1/3 distal dekstra di rsud salatiga. KTI. Surakarta: Universitas Muhammadiyah Surakarta.

Wahyono, Y., \& Budi, U. (2016). Efek pemberian latihan hold relax dan penguluran pasif otot kuadrisep terhadap peningkatan lingkup gerak fleksi sendi lutut dan penurunan nyeri pada pasien pasca orif karena fraktur femur $1 / 3$ bawah dan tibia $1 / 3$ atas. Jurnal Terpadu IImu Kesehatan, 5(1), 01-109. 